\title{
PERAN BIMBINGAN KONSELING TERHADAP BAKAT DAN MOTIVASI BELAJAR PESERTA DIDIK DALAM PROSES PEMBELAJARAN
}

\author{
RAHMI SEPTIA SARI ${ }^{1}$, NEVIYARNI SUHAILI ${ }^{2}$, MUDJIRAN $^{3}$, HERMAN $^{2}$ \\ NIRWANA ${ }^{4}$ \\ Apikes Iris Padang ${ }^{1}$, Universitas Negeri Padang ${ }^{2,3,4}$ \\ rahmiseptiasari88@gmail.com, neviyarni.suhaili11@gmail.com, \\ mudjiran.unp@gmail.com, herman.nirwana@yahoo.com
}

\begin{abstract}
Learning is needed for every person or individual, because by learning someone will gain knowledge and cause changes in behavior, by learning a child will make adjustments that require motivation and talent. A skill is an intelligence that already exists in an individual that can be developed through motivation that comes from a good environmental response. When students have competence obtained from their will, students can complete the exercises given correctly in learning activities, so that students are easier to achieve. In this case motivation has an important role to achieve goals by influencing students to try to achieve them. goals in the form of actions and behavior according to their abilities. Counseling guidance plays a role in the development of students' abilities as a motivation that encourages students to develop these talents. Teacher guidance looks very influential for the smooth learning process. In learning the teacher's behavior greatly affects students' learning motivation, so that social support interactions occur in the form of providing information, emotional attention that helps students overcome problems that hinder their motivation to develop the talents that already exist in them. The counseling guidance provided by the BK teacher also helps them to be able to restore their confidence in learning
\end{abstract}

Keywords: Counseling Guidance, Talent, Motivation, Learning Process.

\begin{abstract}
Abstrak: Belajar diperlukan bagi setiap orang atau individu, karena dengan belajar seseorang akan memperoleh pengetahuan dan menimbulkan perubahan tingkah laku, dengan belajar seorang anak akan melakukan penyesuaian-penyesuaian yang memerlukan motivasi dan bakat yang dimiliki. Suatu keahlian merupakan kepandaian yang telah ada dalam diri individu yang dapat dikembangkan melalui motivasi yang berasal dari respon lingkungan yang baik. Ketika peserta didik memiliki kompetensi yang didapat dari kemauannya maka peserta didik dapat menyelesaikan latihan yang diberikan dengan benar dalam kegiatan pembelajaran, sehingga peserta didik lebih gampang untuk mencapainya.dalam hal ini motivasi memiliki peran penting untuk mencapai tujuan dengan jalan mempengaruhi peserta didik untuk berusaha untuk mencapai tujuan dalam bentuk tindakan dan tingkah laku sesuai dengan kemampuannya. Bimbingan konseling ikut berperan dalam pengembangan kemamuan peserta didik sebagai motivasi yang mendorong peserta didik untuk mengembangkan bakat tersebut. Bimbingan guru terlihat sangat berpengaruh bagi kelancaran proses pembelajaran. Dalam pembelajaran perilaku guru sangat mempengaruhi motivasi belajar siswa, sehingga terjadi interaksi dukungan sosial berupa pemberian informasi, perhatian emosional yang membantu siswa mengatasi masalah yang menghambat motivasinya untuk mengembangkan bakat yang sudah ada pada dirinya. Bimbingan konseling yang diberikan oleh guru BK juga membantu mereka untuk dapat mengembalikan kepercayaan dirinya dalam belajar
\end{abstract}

Kata Kunci: Bimbingan Konseling, Bakat, Motivasi, Proses Pembelajaran. 


\section{A. Pendahuluan}

Belajar tanpa ada motivasi dari guru akan membuat siswa menjadi tidak bersemangat untuk mengikuti pelajaran. seharusnya proses pembelajaran di iringi dengan factor pendukung berupa bakat dan motivasi sehingga pembelajaran sangat menyenangkan. Bakat adalah sebuah kemampuan atau potensial diri seseorang ketika melakukan kegiatan yang memerlukan usaha yang lebih giat dan efektif. Bakat sendiri terlahir dari kemampuan diri sendiri yang terbentuk dari kemampuan yang telah ada sejak lahir, dengan adanya bakat tadi, peserta didik akan lebih mudah untuk memperoleh keinginan yang lebih terarah dalam belajar. Dalam hal ini peran bimbingan konseling dalam mengarahkan peserta didik untuk penjurusan bidang ilmu sangat penting sekali, sehingga peserta didik tidak canggung ketika memilih atau menentukan pengembangan diri sesuai potensi bidang ilmunya.

Bakat dalam hal ini hampir sama dengan suatu keahlian atau kepandaian yang nantinya dapat dijadikan sebagai pendorong bagi peserta didik dalam mencapai tujuan pendidikan yang diharapkan. Keahlian dalam diri peserta didik dapat dikembangkan melalui pelaksanaan pembelajaran disekolah maupun lingkungan formal lainnya, keahlian tersebut dapat dikembangkan sesuai dengan keahlian dan peminatan yang telah dipilih oleh peserta didik tersebut. Untuk melahirkan motivasi untuk mengembangkan bakat siswa tidak terlepas dari pengaruh guru dan guru bimbingan konseling yang menjadi media untuk pendorong siswa tersebut.

Masalah yang muncul pada siswa dan masyarakat adalah menganggap bahwa BK hanya menangani anak- anak bermasalah dan memberikan hukuman kepada yang melanggar, dan beranggapan anggapan negatif yang di timbulkan disekolah berasal dari tidak berfungsinya layanan BK di sekolah tersebut. Sehingga dalam hal ini dapat kita lihat bahwa prilaku guru secara langsung maupun tidak langsung mempunyai pengaruh terhadap motivasi dan bakat belajar siswa, baik yang sifatnya positif maupun yang negative.

\section{B. Metodologi Penelitian}

Metodologi penelitian yang dipakai disesuaikan dengan tujuan penelitian ayang akan memabahas peran bimbingan konseling terhadap bakat dan motivasi belajar peserta didik dalam proses pembelajaran.

\section{Hasil dan Pembahasan \\ 1.Bimbingan Konseling}

Bimmbingan dan konseling merupakan bagian yang tidak dapat dipisahkan dari dunia pendidikan. Peran bimbingan konseling secara khusus dapat mengoptimalkan pengembangan diri siswa, peserta didik menjadi sasaran utama guru Bimbingan konseling di sekolah. Layanan diberikan kepada konseli sesuai kurikulum yang berlaku. Adapun tujuan bimbingan koseling adalh untuk tujuan nasional pendidikan yang mampu untuk merancang masa depan manusia untuk menjadi berguna. Tujuan bimbingan dan konseling adalah sama sebagai tujuan dari nasional pendidikan, yaitu mengetahui lingkungan, meningkatkan kualitas pendidikan dan menjadi mampu merancang masa depan untuk menjadi manusia yang bergun.

Peran guru sangat berpengaruh terhadap proses belajar mengajar, sehingga guru yang profesionala akan mempengaruhi kegiatan tersebut sehingga memotivasi siswa untuk mengembangkan bakat yang dimiliki, dalam hal ini guru yang professional yang dimaksud adalah guru BK, guru yang memiliki wewenang untuk bertanggungjawab dalam pelaksanaaan bimbingsn konseling terhadap siswa, guru bertugas terkait 
pengembangan diri peserta didik sesuai dengan kebutuhan, potensi, bakat, minat dan kepribadian siswa disekolah.

\section{Bakat}

Menurut Sukardi (2003) bakat adalah su atu k eadaan yang terdapat dalam diri individu yang dapat melakukan perubahan ke keadaan yang lebih maju . keahlian yang di sebut dengan bakat tadi tidak akan mudah untuk berubah dan biasanya akan bersifat tetap dalam diri peserta didik.keahlian ini berperan penting dalam peningkatan kualitas dan mutu suatu pendidikan dimiliki seseorang. Menurut Wiliam (dalam Sumadi Suryabrata, 2010) bahwa bakat adalah keahlian seseorang untuk melaksanakan suatu usaha yang tidak membutuhkan latihan-latihan ulang untuk membiasakan tugas tertentu. Keahlian dapat diperoleh dari sejak lahir oleh peserta didik yang bisa dikembangkan karena adanya kolaborasi antara pengetahuan dengan praktek potensi yang dimiliki peserta didik. Dalam hal ini dapat dikemukakan, suatu keahlian dapat dilihat dari usaha atau kemampuan yang dilakukan peserta didik untuk pengembangan diri yang terarah dan terprogram sesuai tujuan yang ingin dicapai peserta didik tersebut.

Bakat dapat didefinisikan sebagai keadaan kompetensi peserta didik dalam menanggapi potensi dirinya untuk melaksanakan pekerjaan sesuai dengan keahlian mereka, Branca mendefinisikan bakat sebagai: keahlian yang ada pada diri individu yang dapat dikembangkan sesuai kemampuan yang ada pada dirinya . Menurut Crow \& Crow mengatakan bahwa: "Bakat merupakan suatu output yang tampak dalam perilaku seseorang dalam mengembangkan keahlian yang ada pada diri guna mengekspresikan kemampuan tersebut dalam bentuk keterampilan-keterampilan khusus yang bermanfaat seperti keahlian keahlian di bidang tertentu sesuai keilmuan yang berkembang pada saat ini.

\section{Motivasi}

Motivasi merupakan suatu kondisi yang dapat di inisiasi, pemandu dan pengarah prilkaku dalam suatu tindakan yang pada akhirnya terbentuk suatu kondisi yang lebih baik. dalam hal ini motivasi jiuga dapat diartikan sebagai sebuah pendorong yang mempengaruhi suatu keadaan yang dapat dijadikan sebagai suatu usaha untuk menjalankan tujuan dalam bentuk prilaku yang nantinya berpengaruh terhadap keadaan semula. Dengan motivasi adanya upaya penggerak suatu kegiatan tercipta dan menghasilkan suatu perlakuan positif. Dorongan yang kuat dalam diri seseorang untuk memulai suatu kegiatan merupakan suatu motivasi dalam melaksanakan tidakan yang ingin dilakukan untuk mencapai tujuan. Dalam melakukan suatu usaha tidak terlepas dari suatu usaha yang mengendalikan seseorang sebagai pendorong tercapainya suatu keinginan yang diharapkan, sehingga dalam hal ini tujuan akan diperoleh hasil yang baik.

Ketika seseorang mengansumsikan bahwa dalam dirinya akan termotivasi jika ada hal-hal yang baik yang mampu mendorong keinginan mereka untuk melakukan sesuatu yang pada akhirnya memperoleh suatu yang di inginkan. Kalau dalam dunia pendidikan dapat diartikan bahwasanya motivasi dapat dijadikan sebagai sebuah pendorong diri mereka untuk mencapai hasil belajar yang baik dengan cara melakukan tindakan berupa prilaku dan tindakan positif seperti dengan cara belajar yang baik, dan selalu menanamkan dalam diri untuk selalu berprilaku jujur dalam melakukan hala-hal dalam belajar. Dengan adanya motivasi sebagai wadah penghantar seseorang untuk 
bertindak dan berprilaku, hal ini menjadikan sbuah motivasi akan menghasilkan suatu capaian berupa pengetahuan baru yang dapat diaplikasikan dalam kehidupan.

\section{Belajar}

Pendapat Chatarina (2006:5) yang menyatakan bahwa belajar sangat penting bagi perkembangan manusia, perilaku, keyakinan dan kepribadian. Belajar merupakan suatu usaha untuk memperoleh suatu tujuan yang diinginkan seseorang untuk membentuk suatu pola pikir yang sesuai dengan pengetahuan yang diperoleh dari belajar. Dengan belajar terjadi perubahan perlakuan dari hasil aplikasi pengetahuan yang telah dipelajari.menurut slavin belajar merupakan proses berubahnya tingkahlaku dari pengalaman yang berasal dari penyelesaian tugas-tugas tertentu. Dengan belajar dapat terlihat suatu proses yang disadari dari kegiatan belajar. Suatu kemampuan peserta didik dapat dikembangkan melalui belajar yang bertujuan untuk menambah ilmu pengetahuan

Tujuan pembelajaran dapat berorientasi pada skor yang ditemukan dalam hasil evaluasi yang diperoleh siswa. Dengan adanya evaluasi yang dilakukan melalui tes hasil belajar maka akan terlihat bagaimana hasil dan evaluasi tujuan yang diharapkan dari pembelajaran.

\section{Bimbingan Konseling Sebagai motivasi Pengembangan Bakat Siswa}

Tenaga pengajar dan guru BK di sekolah memiliki tanggung jawab untuk membimbing peserta didik dalam mengembangkan potensi diri yang terlihat pada diri masing-masing peserta didik. Dalam hal ini perlu digali kemampuan peserta didik yang seharusnya dapat dikembangkan dengan berbagai dorongan dari lingkungan seperti di lingkungan sekolah maupun masyarakat. Di lingkungan sekolah guru BK akan membimbing untuk mengarahkan peserta didik dalam memilih jurusan yang nyambung dengan kemampuan peserta didik. Guru BK memiliki tugas untuk menjadi motivator dan fasilitator untuk pengembangan keahlian, Guru BK akan memberikan masukan dan solusi-solusi yang tepat sesuai dengan kemampuannya sehingga dalam hal ini peserta didik tidak salah memilih jurusan sesuai dengan keahlian mereka dalam pembelajaran.

Pendidik dan guru BK dalam pengembangan kemampuan peserta didik berusaha untuk menjadi pembimbing yang mengarahkan peserta didik. Dalam hal ini dapat mengembangkan kemampuan siswa untukberkembang sesuai bidang keahlian mereka. Pendidik dan guru BK dalam memotivasi siswa untuk mengembangkan minat dan bakat siswa memerlukan cara dan teknik, diantaranya dengan cara mengenali minat dan bakat siswa terlebih dahulu. Siswa akan mengikuti pembelajaran untuk memperoleh pengetahuan, setelah itu akan terlihat perubahan dari pengetahuan yang dimiliki siswa. Selanjutnya guru akan membantu mengembangkan potensi siswa tersebut dari motivasi yang terlihat pada siswa dengan selalu mengarahkan siswa melalui pembelajaran yang terarah.

Guru BK di sekolah akan berusaha untuk membantu siswa sebagai pemberi arahan kepada peserta didik untuk mengembangkan kemampuan diri yang ada sejak lahir berupa bakat. Kemampuan tersebut pada peserta didik dapat terlihat ketika mereka mengikuti suatu proses pembelajaran yang mempengaruhi tingkah laku dan pengetahuan yang diperoleh dari belajar. Prestasi belajar dapat di peroleh dari pengembangan bakat siswa yang telah dibimbing oleh guru. Untuk mengembangkan keahlian tersebut membutuhkan dorongan yang mendukung untuk mencapai hasil yang diharapkan. Pada saat belajar guru harus bisa melakukan pengamatan terhadap 
kemampuan keahlian peserta didik yang merupakan kemampuan lahiriah yang dibawa sejak lahir, sehingga dengan demikian guru akan lebih mudah untu mengarahkan mereka sesuai dengan keahliannya. Pengembanagn program belajar disekolah harus memperhatikan bagaimana minat dan bakat belajar peserta didik pada saat orientasi mengikuti pembelajaran sekolah.

\section{Penutup}

Bakat merupakan acuan untuk pencapaian hasil yang ingin dicapai dalam pembelajaran yang dimualai dengan penjelasan tentang ilmu pengetahuan yang di lanjukan dengan sebuah kemampuan keahlian yang di dorong dengan kemauan dan keinginan belajar siswa yang di jadikan sebagai sebuah motivasi untuk mencapai suatu tujuan. Dengan adanya potensi yang dimiliki peserta didik. Pengembangan potensi akan lebih terarah dengan adanya bimbingan dari guru BK. Guru BK memiliki tanggungjawab untuk mengarahkan peserta didik dalam mengembangkan minat dan bakat mereka, ketika peserta didik mengalami kesulitan dalam mengembangkan keahlian, maka guru BK akan memberikan solusi dan jalan keluar dari permaslahan yang dihadapi. Guru BK dikatakan berkompeten apabila dapat melakukan kegiatan pembelajaran secara professional sesuai program yang telah dirancang sesuai ketentuan yang berlaku di sekolah tersebut . dalam hal ini Guru harus mampu menjadi media pendukung bagi siswa dalam mengembangkan ilmu pengetahuan sesuai dengan bakatnya, keikutsertaan peserta didik dalam kegiatan yang mendukung untuk pengembangan kemampuan dan keahlian peserta didik maka sekolah biasanya memberikan kegiatan ekstrakurikuler yang bertujuan untuk mendukung melahirkan dan mengembangkan kemampuan yang telah ada pada diri peserta didik

\section{Daftar Pustaka}

Arifin , Zainal . 2012. Evaluasi Pembelajaran . Bandung:PT Pemuda Rosdakarya A Tabrani 1989. PendekatanBelajar Mengajar, Remadja Karya , Bandung.

Boud, D., Cohen, R., dan Sampson, J. (2001) Peer learning di pendidikan tinggi: Belajar dari dan dengan satu sama lain. London: Kogan Tekan

Djamarah, 2002. Psikologi Pembelajaran, Jakarta: Rineka Cipta .

Mulyasana, Dedi.2012 . Pendidikan yang Berkualitas dan Berdaya Saing . Bandung: PT. Pemuda Rosdakarya .

Munandar, Utami . (1999). Kreativitas dan Bakat (strategi untuk mewujudkan potensi dan bakat kreatif). Jakarta: Gramedia Pustaka Utama .

Rothbart, MK \& Bates, JE (1998). Perangai. Dalam W. Damon (Ed.), Handbook of Child Psychology ( edisi ${ }^{\text {ke- }} 5$. , Vol.3 ). New York : wiley

Santrock, John, W. (2009). Psikologi Pendidikan ( Ed.4 ). New York. Bukit McGraw. membanting . (1991). Belajar dan Faktor yang Mempengaruhi Ini . Jakarta: Bumi Literasi.

Sardiman . 2007 . Interaksi Belajar Mengajar dan Motivasi . Jakarta: Rajawali Press

Siregar, Eveline dan Nara, Hartini.2011. Belajar dan Belajar Teori . Bogor: Ghalia Indonesia.

Sidjabat . BS 2000. Menjadi Guru Profesional : Perspektif Kristen, Bandung:...

Suyanto , Asep Jihad. 2013. Menjadi Guru Profesional: Strategi Meningkatkan Kualifikasi dan Kualitas di Era Globalisasi . Jakarta: Esensi

UU RI No. 20 Tahun 2003 tentang Sistem Pendidikan Nasional.

Winkel , . Pengajaran Psikologi, Jakarta: Gramedia , 1996 
Wijaya , Cece dan Tabrani Rusyan . 1991. Kemampuan Dasar Guru dalam Mengajar dan Belajar Proses . Bandung : Pemuda Rosda Karya . 